\title{
Hunting Tourism as a Modern Product for the Development of Czech Regions
}

\author{
Markéta KALÁBOVÁ \\ University of Economics in Prague, Prague, Czech Republic \\ marketa.kalabova@vse.cz
}

\begin{abstract}
Hunting tourism is good opportunity for rural regions in the Czech Republic. The aim of this article is to determine which areas have potential for hunting tourism and where it would be appropriate to actively focus on promoting hunting tourism. Potential was evaluated on the base of annual hunt per hectare as the maximum offer of an area. Data were collected for municipality with extended power as the smallest territorial unit in the Czech Republic. Hunt of furry game and feathered birds were calculated separately. Results of research were demonstrated by cartograms. Data were collected from The forest management institute. Totally $34 \%$ of the territory is suitable for the development of hunting tourism of furry game and $18 \%$ of the Czech Republic is suitable for hunting tourism of feathered birds. Mostly north-west of the Czech Republic - Karlovarský region, Plzeňský, Ústecký and some areas in Liberecký and Středočeský region, then Jihomoravský region are very suitable for the development of hunting tourism in terms of furry game. Very good potential for hunting tourism of feathered birds was recorded around rivers Vltava, Labe and Morava.
\end{abstract}

Keywords: Hunting tourism, Regional development, Tour operator

\section{$1 \quad$ Theoretical framework}

\subsection{Hunting tourism}

The issue of wildlife management has been a highly discussed topic in recent years. Hoofed game is overpopulated in some areas in the Czech Republic and hunters fail to reduce their numbers to a standardized numbers. The main task of the paper is to point out the possibilities of hunting in the territory of the Czech Republic in terms of hunting tourism, which in the future could become one of opportunity for the development of rural areas and the development of regions. Most tourists arriving to the Czech Republic go to Prague or the South Bohemian region. However, hunting tourism could attract foreigners into less visited regions and become a great phenomenon of the future.

Game control through hunting is one of the most important game management tools. Overpopulated game pieces cause considerable damages to farmland and forest stands. Based on estimates, annual crop damage ranges from 3.5 to 7 billion 
crowns. [2] Predominantly small farmers have a lot of damage, their competitiveness is reduced and then conflicts between interest groups are taking place. A large number of items also pose a risk for the spread of disease and the subsequent degradation of the entire population. The goal of hunting management in the Czech Republic is above all to take care of game and to increase its value and strength. Offering a part of the planned number of game pieces to foreign hunters can mean a solution to reduce overpopulated game numbers. At the same time, hunting tourism means significant income to the regions, whether in terms of tax hunting or the multiplier effect of consuming services that are important to ensure the hunt. Hunting tourism is very specific form of tourism. The demand for hunting is limited by number of wild animals in area. The higher number of animals per hectare an area has the better opportunity to develop hunting tourism it has.

New forms of tourism, such as agro tourism or ecotourism, under which hunting tourism is often ranked, are a source of valuable effects in the region, as they contribute to improving the quality of tourism services, thereby contributing to the growth of the social and economic potential of the area. [5]

The benefits of hunting tourism can only be enjoyed under the conditions of sustainability. Sustainable development of hunting tourism can be achieved by preserving environmental sustainability, economic viability and social adequacy. [3] Each of these pillars of sustainable hunting development, however, contains a great deal of problems and is so important for many scientists dealing with the issue. For example, Woodroffe and Ginsberg [7] consider that hunting tourism must also be useful for the conservation of natural habitats and contribute to the protection of wildlife, in order to achieve environmental sustainability. According to Morrill [8], hunting is less destructive than other forms of ecotourism, such as photographic tourism. The same view is held by Gössling [4]. According to him, hunters have less impact on the environment than photographers, as they do not require so much local amenities and infrastructure, which significantly reduces the degradation of the habitat.

According to the advice of the International Council for Game and Game Conservation (CIC) [1], the sustainable form of hunting tourism is one of the game's protection tools, as well as the use of natural resources, which can play a key role in reducing rural poverty. In many countries, especially in the developing world, organized hunting tourism has risen sharply in the last half-century. This trend is great economic and ecological importance. For the host country and its rural population, hunting tourism has a number of advantages - preserving ecosystems, generating income and employment in less-favored areas, economic and sensible use of natural habitats that are not suitable for agriculture or conventional tourism, building awareness among the local population the value of wild game that is otherwise considered to be harmful, disturbing and costly, to reducing the environmental impact compared to other forms of tourism and reducing poaching through the joint efforts of all those who are interested in generating income from hunting tourism [1]. 


\subsection{Hunting possibility in the Czech Republic}

In the Czech Republic there is possible to hunt furry game, mostly hoofed game such as red deers, roe deers, fallow deers, moufflons and wild boars. Small furry game is represented by hares, foxes, badgers and martens; even so just hares are objects of offer for hunting tourism as a motivation to go to different place for a hunt. It is also possible to hunt feathered birds from which mostly ducks and pheasants form offer for hunters.

\section{$2 \quad$ Methodology}

Potential of regions if they are suitable for the form of hunting tourism was evaluated on the base of annual number of hunt within municipality with extended power as the smallest territorial unit in the Czech Republic. To avoid data distortion in relation to different size of municipalities, number of hunt were recalculated per hectare. Hunt of furry game and feathered birds were calculated separately. Results of research were demonstrated by cartograms. Data were collected from The forest management institute.

\section{$3 \quad$ Results of research}

\subsection{Annual hunt of furry game}

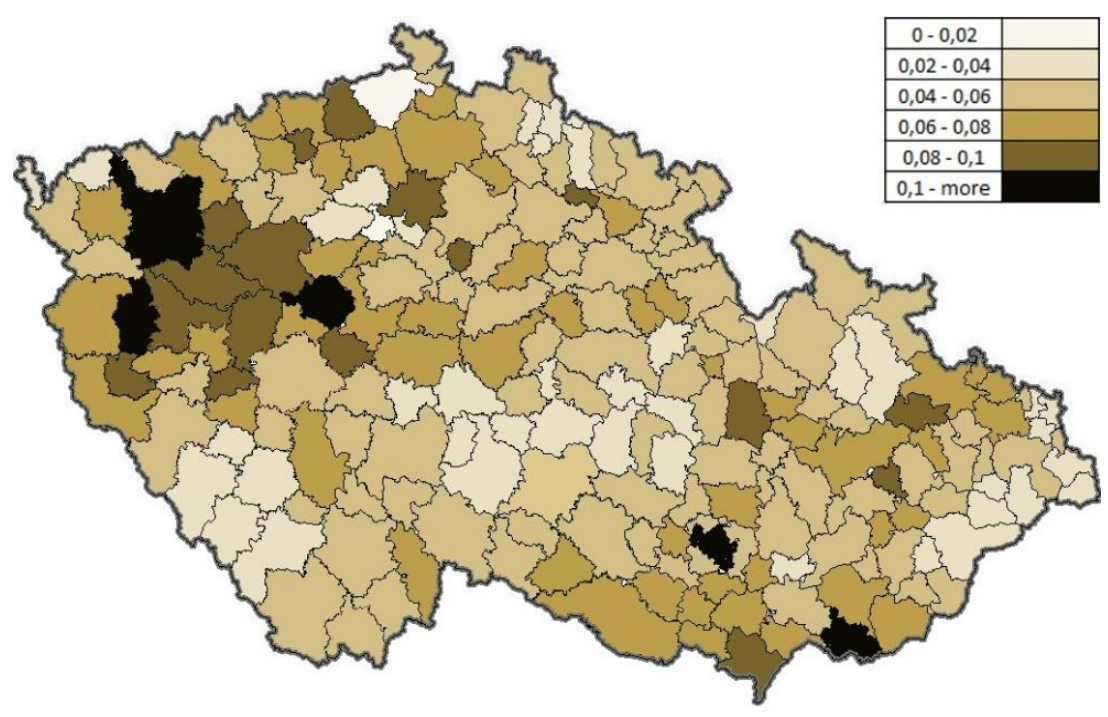

Fig. 1. Annual hunt of furry game per hectare

Municipality with extended power which has higher number of annual hunt than 0,06 pieces per hectare is considered as an area with great potential for the development of 
hunting tourism. According to cartogram above it is visible that very suitable area for the development of hunting tourism is north-west of the Czech Republic, thus Karlovarský region, Plzeňský, Ústecký and some areas in Liberecký and Středočeský region. Also Jihomoravský region has good potential for the development of hunting tourism. Totally $34 \%$ of the territory is suitable for the development of hunting tourism. In detail very high annual hunt of furry wild animals (more than 1 per hectare) was recorded in the following municipalities - Beroun, Karlovy Vary, Stř́bro, Veselí na Moravě. (Brno was excluded because small hunting area). High annual hunt of furry game was recorded in municipalities - Bílina, Blovice, Břeclav, Dobříšs, Horšovský Týn, Kralovice, Lipník nad Bečvou, Lysá nad Labem, Mělník, Moravská Třebová, Nová Paka, Nýřany, Podbořany, Rakovník, Rokycany, Ústí nad Labem and Vítkov. Jihočeský and Vysočina region have very weak potential for the development of hunting tourism in terms of furry game.

\subsection{Annual hunt of feathered birds}

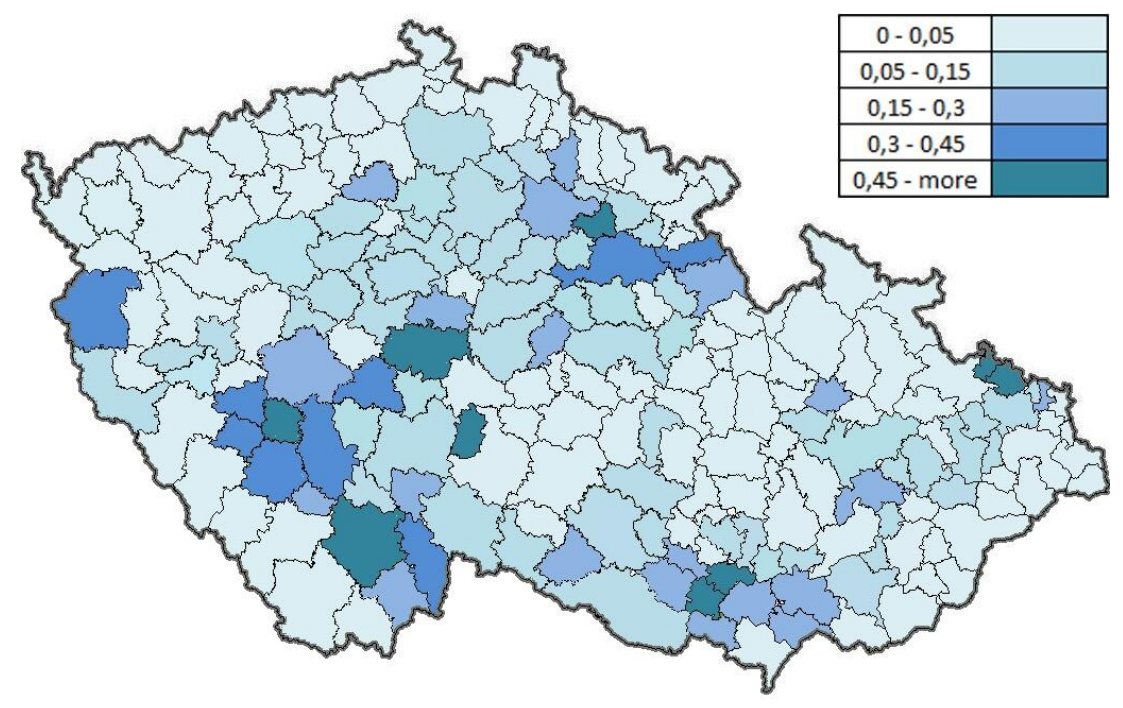

Fig. 2. Annual hunt of feathered birds per hectare

In terms of feathered birds, which can be hunted in the Czech Republic, it was established, that municipality with extended power which has higher annul hunt than 0,15 pieces per hectare is suitable for the development of hunting tourism. According to cartogram above it is visible that very suitable areas for the development of hunting tourism are parties around rivers - Vltava, Labe and Morava. Totally $18 \%$ of the Czech territory is suitable for the development of hunting tourism. Municipalities with extended power which have very higher annul hunt of feathered birds (more than 0,45 pieces per hectare) are Benešov, Blatná, České Budějovice, Hlučín, Hořice, Kravaře, Pacov, Pohořelice a Židlochovice. High annual hunt of feathered birds was recorded in following municipalities - Dobruška, Horažd'ovice, Hradec Králové, 
Nepomuk, Písek, Sedlčany, Strakonice, Tachov and Třeboň. Vysočina region, Zlínský, Olomoucký, Karlovarský region have very weak potential for the development of hunting tourism of feathered birds.

\section{Conclusion}

Game hunting is an important instrument of game management in the Czech Republic. Wildlife is a national asset and must be properly taken care in order to preserve the highest quality genofond. Hunting tourism has many advantages. Not only it can be a solution to reduce overpopulated game, but it can also be a source of income for regions that are not suitable for classic tourism. Based on data evaluation for individual municipalities with extended power, it can be concluded that the largest offer in terms of the number of planned annul hunt of furry game is distributed unequally, mostly in north-west territory of the Czech Republic. High numbers of annual hunt of feathered birds were recorded around main Czech rivers - Vltava, Labe and Morava. All municipalities with very high or high numbers of annual hunt should develop possibility of hunting tourism. They should build appropriate infrastructure for hunters. Invest into building accommodation and also promote the area as hunting destination suitable for certain hunt. Very desirable and beneficial would be promotion of hunt in foreign countries, because foreign hunters spent more money for a hunt.

Acknowledgements. The contribution was processed within the project Economic, security and system changes in international tourism (Ekonomické, bezpečnostní a systémové změny v mezinárodním cestovním ruchu) - IG206017.

\section{References}

1. CIC: Sustainable hunting tourism - Position paper of the CIC tropical game commission. http://ftp.fao.org/docrep/fao/010/aj114e/aj114e04.pdf, last accessed 2016/02/15

2. Zvěř způsobí podle zemědělců na polích ročně miliardové škody, https://www.denik.cz/ekonomika/zver-zpusobi-podle-zemedelcu-na-polich-rocnemiliardove-skody-20130321.html, last accessed 2017/09/17

3. Deere, J. N.: Environment magazine : Exploitation or Conservation? Can The Hunting tourism Industry in Africa Be Sustainable? http://www.environmentmagazine.org/Archives/Back\%20Issues/2011/JulyAugust $\% 202011 /$ exploitation-or-conservation-full.html, last accessed 2017/03/09

4. Gössling, S.: Tourism: A Sustainable Development Option, Environmental Conservation 27(3), 223-24 (2000)

5. Lacina, K.: Tourism industry regional aspects. In Klímová, V., Žítek, V. (eds.) XVI. mezinárodní kolokvium o regionálních vědách, pp. 629-635, Masaryk University, Brno (2013). DOI: 10.5817/CZ.MUNI.P210-6257-2013-79

6. NPP. NORTHERN PERIPHERY PROGRAMME: North hunt - sustaianable hunting tourism 
http://www.northernperiphery.eu/files/archive/Downloads/Project_Publications/9/Brochur e\%20in\%20English.pdf, last accessed 2017/02/12

7. Woodroffe, R., Ginsberg, J. R.: Edge Effects and the Extinction of Populations Inside Protected Areas. Science 280 (7), 2126-2128 (1998) DOI: 10.1126/science.280.5372.2126

8. World Bank: The Tourist Safari Hunter's Role in Conservation, in Living With WildlifeWildlife Resource Management With Local Participation in Africa - Appendix II, World Bank, Washington, DC, (1990). 